\title{
Model of effective partnership between government and business in the course of the implementation of regional infrastructure projects
}

\author{
Elina Gabidullina*, Irina Gavrilenko, and S. Rastegaev \\ Ufa State Petroleum Technological University, Chernyshevsky str., 145, 450578 Ufa, Russia
}

\begin{abstract}
The aim of the article was to develop recommendations for increasing the socio-economic and budgetary efficiency of investments in the regional infrastructure of public utilities on the basis of public-private partnerships. The main problems of the practical implementation of public-private (PPP) (municipal-private (MPP)) partnership projects in the communal complex of the Republic of Bashkortostan are identified and systematized. The necessity of using modern information technologies in the implementation of PPP projects is substantiated to simplify the system of interaction between three different categories of users, business, government and the local community. A model of effective partnership between government and business in the implementation of a municipal heat supply project is proposed. The proposed author's model is based on a comprehensive consideration of the interests of all parties involved in the project (investor, producer, consumer of services, authorities, local community). It contributes to the determination of economic, social and environmental efficiency. The main provisions and conclusions of the study can be used in state and municipal programs to support public and municipal-private partnerships. The theoretical and applied problems of establishing unified, universal mechanisms for the development of regional infrastructure require special attention. These mechanisms are based on the use of models for the optimal choice of priority investment projects for territorial development.
\end{abstract}

\section{Introduction}

Among the main directions of the spatial development of the Russian Federation regions, the elimination of infrastructural restrictions in the socio-economic development of territories, an increase in the availability and quality of the main transport, energy and information and telecommunications infrastructure are distinguished. The level of development of the regional infrastructure, as much as anything else, determines the investment attractiveness of the region and its competitiveness. It is a necessary

\footnotetext{
*Corresponding author: elya_gabi@mail.ru
} 
prerequisitefor the placement of productive forces in all their components. Eventually, it is a factor in ensuring sustainable socio-economic growth of the territory.

In this regard, the question of what measures (instruments) of the state regional policy can be used to solve the problem of implementing infrastructure projects is being actualized.

It is necessary to establish unified, universal mechanisms for the development of regional infrastructure, based on the use of models for the optimal selection of priority projects, analysis of investment opportunities, justification of the priority of government and business participation in the implementation of projects, and assessment of socioeconomic efficiency.

In conditions of significant limited regional and municipal budgets, the implementation of infrastructure projects is impossible without attracting private capital. Only effective, mutually beneficial interaction between state and business structures can overcome the infrastructural backwardness of Russian regions.

In domestic and foreign economic literature, considerable attention is paid to researching the processes of partnership between business and government in the implementation of infrastructure investment projects.

Among the domestic scientists who influenced the development of regional theory in the field of distribution of productive forces, the development of regional infrastructure, it is necessary to single out E.M. Buchwald, A.G. Granberg, B. Lavrovsky, A.V. Suvorov, A.I. Tatarkin, Yu.N. Shedko, A.G. Shelomentsev [2-8]. R. Akhunov, D.A. Gaynanov, F.N. Garipov, H.N. Gizatullin [9-12] and others are engaged in the issues of uniformity of the socio-economic development of the Republic of Bashkortostan and its municipalities.

The research of theoretical and applied problems of investment development of communal infrastructure is the subject of the works of V.B. Zotova, P.V. Kukhtina, Yu.F. Simionova, R. Zh. Siradzhinov [13-16]. A.A. Alpatov, D. Delmon, V.L. Eremin, E.R. Yescombe, Yu.Yu. Kuporov [17-21] and many more made a significant contribution to the study of public-private partnership mechanisms in Russia and abroad.

The object of the researchis the infrastructure of communal supply of the Republic of Bashkortostan.

The subject of the research is a set of organizational, economic and legal relations arising in the process of implementing regional infrastructure projects on the basis of public-private partnerships.

\section{Materials and Methods}

The theoretical basis of thestudy is the works of domestic and foreign specialists dealing with the problems of implementing investment projects in regions and municipalities on the basis of public-private partnerships.In addition, materials of scientific and practical conferences were used, which applied to the set goals and objectives of the research. The information base was the materials of the Federal State Statistics Service of the Russian Federation and the Territorial Body of the Federal State Statistics Service for the Republic of Bashkortostan, regulatory legal acts, reference, scientific and journalistic materials on the topic under consideration.

The research methodology is based on the use of a systematic approach to the formation of a model of effective partnership between government and business in the implementation of infrastructure projects in the region.

During the research, we used abstract-logical, empirical, statistical-probabilistic methods, methods of observation and expert assessments, cause-and-effect analysis, and the method of simulation. 


\section{Results and Discussion}

1) The reasons hindering the development of PPP in the communal complex of Russia, and the Republic of Bashkortostan were revealed and systematized.

The main problems of the practical implementation of PPP projects in public utilities were identified and systematized: low profitability (in most cases, loss-making) of utilities, insufficient elaboration of the regulatory framework, lack of transparency in the process of tariff setting and financial flows, high investment risks, deterioration of utilities, weak competencies parties to the concession agreement (lack of uniform, understandable and equal rules for control, supervision, monitoring and information support of PPP projects).

2) The necessity of using modern information technologies in the implementation of PPP projects has been substantiated.

In modern conditions of digitalization, the task is to form a base of problems, projects, directions of infrastructure development in the information environment.

So, the purpose of any information system is to obtain, conduct appropriate analytics and subsequent storage of information related to the area for which it was programmed. Also, the goal of the information system created for the PPP sphere is to simplify the system of interaction between three different categories of users: for the population living in the region; for business structures operating in the field of public-private partnership projects; for state and municipal authorities. All this helps to control the processes of the efficiency of enterprises in particular and business structures in general.

A sociological survey was conducted, the main topic of which was to check the level of awareness of citizens of the republic about public-private partnership projects being implemented in the region, and the participation of the business community in resolving issues of life.

During the analysis of the data, it turned out that the overwhelming majority of respondents practically do not know, or do not know enough about the ongoing PPP projects in the Republic of Bashkortostan.

The information system of public-private partnership on the Internet is represented by portals: for training in the conduct of public-private partnership project activities "https://pppcenter.ru", a platform for considering projects "https://rosinfra.ru", the analytical center for PPP "https: //pppcenter.ru ". Their main disadvantages in relation to the Republic of Bashkortostan are:

- lack of opportunity to work with the population and collect certain initiatives;

- a great focus of resources on interaction with large business structures;

- insufficient attention to municipal-private partnership (MPP).

Involvement of the population, public associations and other organizations in solving local issues, including the development of infrastructure for life support, will help to solve many problems more effectively, ensuring mutually beneficial cooperation between the state... "[22], business and consumers.

3) A model for the formation of an effective partnership between government and business in the implementation of infrastructure projects in the region is proposed. The proposed author's model is based on a comprehensive consideration of the interests of all parties involved in the project (investor, producer, consumer of services, authorities, local community). It contributes to the determination of economic, social and environmental efficiency.

The basis of the program for the socio-economic development of any territory is an investment program, including the modernization and technical re-equipment of public utility facilities. The goals are classically:

_ improving the quality and efficiency of infrastructure service systems; 
- improving the quality characteristics of the services provided to the population and economic objects and other consumers of services;

- increasing resource conservation and improving the efficiency of resource use;

- stabilization of tariffs for public services, that is, minimization of the growth rate of prices for consumers.

The implementation of the measures will improve the quality and reliability of resource supply services provided to consumers and, in general, the efficiency of infrastructure (communal) services.

The financing of the investment program activities is usually provided for by means of subsidies from the budget of the Republic of Bashkortostan and the own funds of utilities.

Modernization of resource supply facilities (various resource-providing utilities) will increase efficiency, reduce costs affecting the cost of a service unit, and reduce losses during the transportation of resources by improving the operational properties of utilities.

Thus, we conclude that if you want to build effective relations of PPPs for the development of the territory infrastructure it is necessary to take into account the interests of various participants of this system - a service provider, a consumer of services and an investor, represented by the state (municipality) or business. In addition to improving the life quality of the population, the benefit for the state (municipal) authorities, in this case, will be additional tax and non-tax revenues arising from the implementation of the project.

In the course of the study, a model was developed for the formation of an infrastructure project in the region (using the example of the communal sphere), taking into account their interconnections (Fig. 1). As a result, the criteria for assessing efficiency will be economic, social and budgetary efficiency.

Based on this model, activities to attract infrastructure projects to the development of both the local community (as part of the project base formation) and the municipality (in terms of the assessment of the existing infrastructure base) and business (in keeping with attracting investment) will give a synergistic effect for all participants and society as a whole.

Achieving economic efficiency (using market mechanisms) is implemented through:

- saving budget funds at different levels;

- implementation of potentially (unequivocally) demanded projects and directions;

- formation of investment projects that will be attractive for business;

- incentives for companies developing and servicing infrastructure to find internal reserves for increasing efficiency, stimulating resource and energy conservation. 


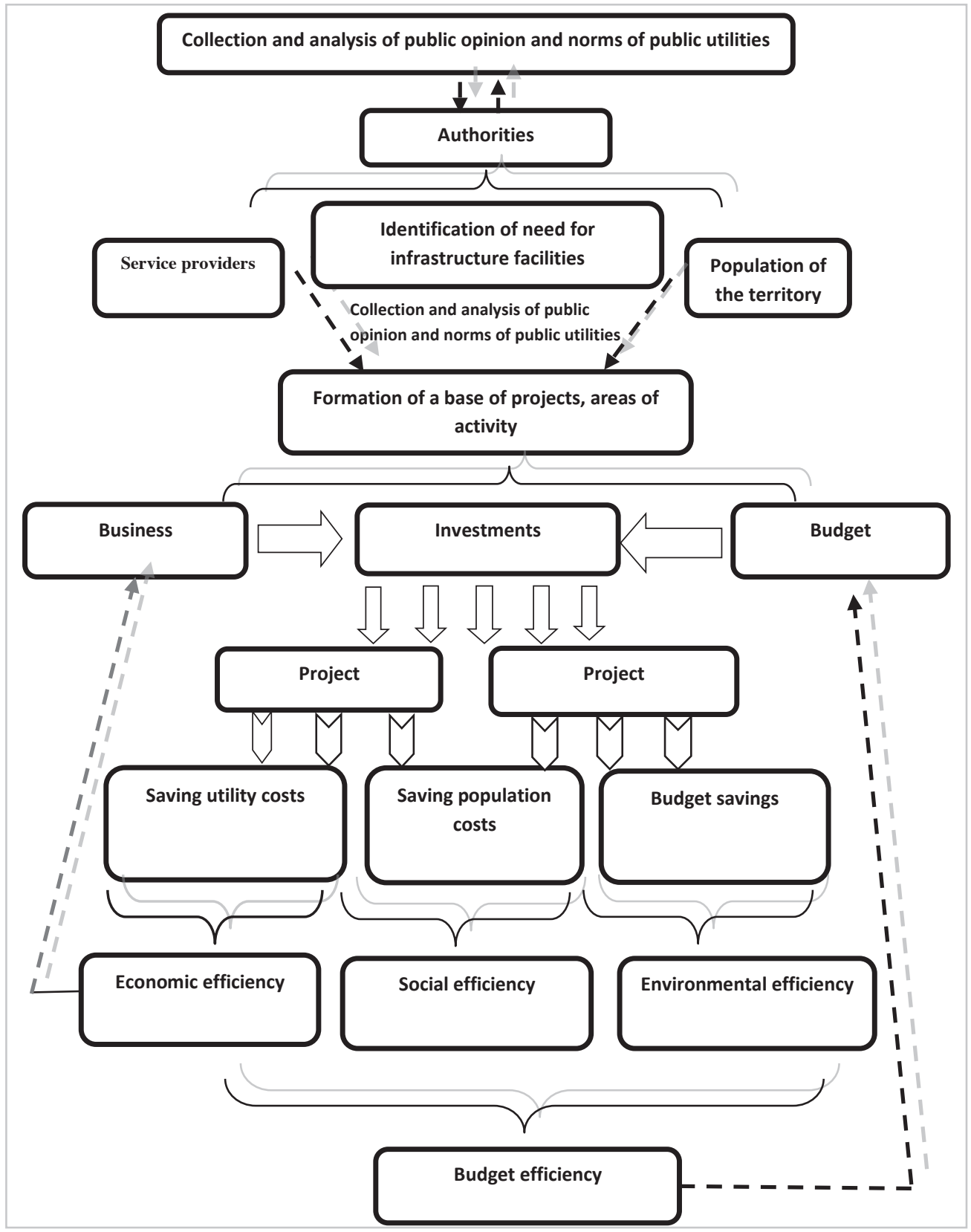

Fig. 1. Model of effective partnership between government and business in the course of the implementation of regional infrastructure projects

When assessing social effects, the following components should be noted:

- increasing the reliability and continuity of the process of providing public services to consumers;

- ensuring (preserving) the economic stability of households due to the stability of utility tariffs;

- improving the life quality of the territory population. 
Concerning the budgetary efficiency of the implementation of PPP projects in the communal sector according to the proposed model, the following points should be noted:

- saving budget funds to maintain the quality of infrastructure facilities;

- an increase in budget savings due to an increment in the use of resource-saving technologies;

- savings due to minimization of damage and consequences of disasters (technological, technical, environmental);

- an increase in budget revenues (tax and non-tax).

\section{Conclusion}

The strategic task of the spatial development of the region can be called the prevention of excessive contrasts in the level of socio-economic development between the center and the periphery. As priority measures to reduce the uneven development of the Republic of Bashkortostan territories in the context of spatial development, we consider the need to implement infrastructure projects (transport, communal, social, recreational, etc.) based on the use of various forms of public-private partnership.

To implement PPP projects effectively, the following points are required:

- increasing the transparency of methods of cooperation between government agencies and business;

- fair distribution of risks among all project participants;

- securing guarantees of return on investment for the investor;

- improvement of the legislative framework related to tariffs to enable the calculation of the efficiency parameters of a PPP project;

- the use of the latest information technologies in the implementation of PPP projects.

The theoretical and applied problems of establishing unified, universal mechanisms for the development of regional infrastructure require special attention. These mechanisms are based on the use of models for the optimal choice of priority investment projects for territorial development.

Comprehensive consideration of the interests of all parties involved in the project contributes to a more accurate accounting of all explicit and implicit costs associated with the implementation of the project, determination of the social significance of the project, both for consumers of services and for society as a whole.

\section{References}

1. Regional development policy in modern Russia: priorities, institutions and instruments: Scientific work, 250 (2018)

2. E.M. Buchwald, A.V. Kolchugin, Self-government, 4,14 (2015)

3. A.G. Granberg, Fundamentals of regional economics: textbook for universities (2001)

4. B. Lavrovsky, State policy of regional development: theoretical questions, Federalism, 4,121(2015)

5. A.V. Suvorova, Journal of New Economy, 3, 51 (2019)

6. A.I. Tatarkin, N.V. Krivenko, N.L. Kuznetsova, Economy of Region, 2, 125 (2015)

7. Yu.N. Shedko, Improvement of management mechanisms for sustainable development of the region: dissertation (2017) 
8. D. Khusainov, A.G. Shelomentsev, S.V. Doroshenko, Economy of Region, 1, 156(2015)

9. R. Akhunov, A. Yangirov, Y. Toktamysheva, A. Rabtsevich, A. Mukhametova, Economics and Management: Scientific and Practical Journal, 6, 9 (2016)

10. D.A. Gainanov, A.G. Ataeva, Bulletin of USPTU, Science, education, economics. Series: The Economy, 1, 7(2019)

11. D.A. Gainanov, A.G. Shelomentsev, A.G. Ataeva, Sociological Research, 10, 64 (2017)

12. F.N. Garipov, H.N. Gizatullin, Z.F. Garipova, Economy of Region, 1, 105 (2016)

13. R.V. Babun, A. N. Kirillova, Municipal governance system, 5th ed., 717 (2010)

14. P.V. Kukhtina, Infrastructure of municipalities, 208 (2008)

15. Yu. F. Simionov, Housing and communal services, Reference, 286 (2010)

16. Urban management, Knorus, 352 (2009)

17. A. V. Pushkin, R. M. Dzhaparidze, Public-private partnership. Implementation mechanisms, 95 (2010)

18. D.Delmon, Public-Private Partnerships in Infrastructure: A Practical Guide for Public Authorities (2019)

19. V.L. Eremin, K.V. Druzhkov, Economics and Mathematical Methods, 4, 111 (2018)

20. E.R. Yescombe, Public-Private Partnership: Fundamental Funding Principles, 457 (2015)

21. Yu. Yu. Kuporov, Socio-economic efficiency of investments in the development of water supply and sanitation services (2017)

22. V.V. Bykov, Local government in the Russian Federation, 44 (2011) 